\title{
The Group Insurance Contract in Private International Law
}

\author{
Mariusz Fras ${ }^{1}$ \\ Published online: 8 November 2019 \\ (c) The Author(s) 2019
}

\begin{abstract}
The provisions on obligations under insurance relationships included in Article 7 of the Rome I Regulation are relatively complicated. However, although individual insurance contracts have their own legal regime in each Member State, only a few national legislators have decided to lay down the consequences of concluding a group insurance agreement. The Rome I Regulation does not include any special conflict of laws rule concerning group insurance contracts, which has been criticized in the literature on the subject.
\end{abstract}

Keywords Private international law · Insurance law · Group insurance contract · Accessory (compulsory) group insurance $\cdot$ Elective group insurance

\section{Introductory Comments}

Upon the entry into force of Regulation (EC) No. 593/2008 of the European Parliament and of the Council of 17 June 2008 on the law applicable to contractual obligations (Rome I) ${ }^{1}$ the regulatory framework of conflict of laws regarding insurance contracts was subjected to far-reaching modifications. The tendency to afford special protection to the 'weaker party' already found its manifestation in Recital 23 of the Regulation, in which it was stipulated that '[a]s regards contracts concluded with parties regarded as weaker, such parties should be protected by conflict-of-law rules that are more favourable to their interests than the general rules'. This thought was developed in sentence 1 of Recital 32, in which it was emphasized that '[o]wing to the particular nature of contracts of carriage and insurance contracts, specific provisions should ensure an adequate level of protection of passengers and policy holders'.

\footnotetext{
1 OJ 2008, L 177/6.

Mariusz Fras

kancelaria-fras@o2.p1

1 Department of Civil Law and Private International Law, Faculty of Law, University of Silesia, Katowice, Poland
} 
It must be noted that the EU legislator avoids using the concept of a consumer when referring to the participants of insurance transactions. ${ }^{2}$ Nevertheless, private international law offers special treatment both to insurance contracts and consumer contracts; however, the legislator applies different protective mechanisms. Whereas in relation to consumer contracts (Art. 6) protection is afforded by means of alternative corrective connecting factors, in the event of insurance contracts the lawmaker has resorted to a less complex solution based on a limited choice of law (Art. 7).

The provisions on obligations under insurance relationships included in Article 7 of the Rome I Regulation are, however, relatively complicated. ${ }^{3}$ Academics ${ }^{4}$ are legitimately objecting and clearly expressing their negative attitude towards the wording of the Article, by calling it a 'labyrinth'5 or even a 'private international law pandemonium'. ${ }^{6}$ The rather opaque character of the said provisions gives rise to doubts as to whether the 'weaker party' is afforded due protection in all situations.

Submitting the insurance contract to a law which is unknown to the policyholder may effectively discourage him from engaging in a legal relationship connected with a foreign legal system. The remedy offered is a progressively expanding conflict of laws mechanism protecting the weaker party in an insurance contract. This tendency, however, may have an effect which is opposite to that which is intended. Differences between specific legal systems and the instruments which are to remove those differences have an impact on the market behaviour of insurers, which refuse to grant insurance protection to entrepreneurs operating small-sized businesses and consumers whose habitual residence is outside the country in which the insurance company is domiciled. ${ }^{7}$

Considering the above, the purpose of this article is to consider issues connected with identifying the proper law for the group insurance contract. This matter has not been resolved in the Rome I Regulation and yet group insurance with cross-national elements is an important section of the insurance market. Furthermore, the article will focus on the characteristics of the group insurance contract in the context of the substantive laws of selected countries. This backdrop will provide an opportunity to present a legal analysis of the different ties that exist among the parties to a group insurance contract and to identify the challenges of properly understanding its legal nature. The conclusions will then allow us to determine what issues concerning the group insurance contract have been resolved in academic writing and in practice and

\footnotetext{
2 Orlicki (2005), p. 423. With a view to retaining terminological consistency with the conceptual framework adopted in the acquis communautaire, certain authors characterize an insurance contract as a contractual obligation with quasi-consumer features. Wojewoda (2007), pp. 91-92.

3 The solutions adopted in Art. 7 of the Regulation have thus far been widely discussed in the domestic literature. See Fuchs (2009), pp. 9-32; Kowalewski and Bzdyń (2012), pp. 67-87; Kropka (2010); Ludwichowska and Thiede (2009), pp. 58-72; Pilch (2012), pp. 313-385.

${ }^{4}$ Heiss (2008a), p. 261; Gruber (2009), p. 110 and the literature cited therein. The solutions adopted by the EU legislator were also criticized by Polish academic authors. Ludwichowska and Thiede (2009), pp. 62-63; Kowalewski and Bzdyń (2012), p. 72.

5 Kramer (2008), p. 41.

6 Heiss (2008a), p. 261.

7 Bucher (2011), p. 209.
} 
which require further consideration, bearing in mind the role that private international law plays when one is dealing with a group insurance contract with international elements.

\section{The Group Insurance Contract in Selected Legal Systems}

All of the provisions on the relations connected with the conclusion and performance of insurance contracts together make up economic insurance law. Because of its objective homogeneity, it is generally dealt with as a separate branch of law. ${ }^{8}$ From a dogmatic perspective, its permanent element is group insurance contracts. However, the results of a comparative law investigation allow the conclusion to be drawn that in a substantial number of legal systems the term 'group insurance' is not to be found in legislation. ${ }^{9}$ Even in systems recognizing the need to specifically regulate the group insurance contract, the prevalent tendency is to regulate this subject matter in a rudimentary fashion.

It should be pointed out that as compared to individual insurance, in which all risks focus, in principle, on one party, in the collective type of insurance contract the risk is spread over a certain number (a group) of insured parties. As a consequence, the collective insurance contract is an example of the multiplication of the number of persons involved in the insurance relationship. Insurance contracts may therefore be generally divided into individual and collective insurance according to the number of persons covered by insurance protection. ${ }^{10}$ The dissimilarities between individual and collective insurance contracts are manifest, among others in respect of the following issues: the conclusion of the insurance contract, the legal nature of the insurance contract, the scope of insurance protection, the methods of extending insurance protection during the insurance relationship to such persons that originally, upon the conclusion of the insurance contract, did not enjoy protection, as well as insurance administration or assessment and the selection of risk. ${ }^{11}$

One of the few exceptions to the rule that the legislator does not usually define a group/collective insurance contract is France, where group insurance attracted the special attention of the legislator. French insurance law is composed of a number of legislative acts, ${ }^{12}$ which include multiple solutions that are distinctive when compared to other European legislations. Among the solutions that are almost exclusively specific to French law, one can also point out the extensive regime of group insurance contracts. ${ }^{13}$ Complications following from the application of those provisions are subject to detailed doctrinal discussion.

\footnotetext{
8 Kowalewski (2006), pp. 84-85.

9 Loacker (2015), p. 226.

10 Handschke, Kęszycka and Kowalewski (2007), p. 3.

11 More from the economic perspective in Łyskawa (2007), pp. 153-156.

12 Bigot-Gonçalves (2009), p. 49.

13 Bigot-Gonçalves (2009), p. 22.
} 
The contemporary catalogue of French sources of insurance law constitutes a very extensive system of interrelated normative acts. One may only speak of coherent statutory solutions in the case of one of the types of collective insurance agreements, namely the group insurance contract. Other collective insurance contracts do not form any homogenous category and are characterized by the absence of coherent systemic solutions.

The basic French legislative act covering problems relating to insurance law is the Insurance Code (CA). ${ }^{14}$ Its field of application ratione personae precludes recourse to the solutions envisaged in the Code with regard to contracts in which the party affording insurance protection is an entity other than a joint-stock company pursuing insurance activities. ${ }^{15}$ The provisions of the Code do not apply to contracts concluded by mutual insurance societies or social security institutions. ${ }^{16}$ This gap, however, is filled by other codes: the Mutual Insurance Code (Code de la mutualité) ${ }^{17}$ and the Social Security Code (Code de la sécurité sociale). ${ }^{18}$

Besides the Insurance Code, the foundation of modern legislation on collective group agreements, as a wider category covering, among other things, group insurance contracts, is laid down by two Acts of 31 December 1989, namely Act No. 89-1009 reinforcing the safeguards for persons insured against certain types of risk, ${ }^{19}$ referred to as loi Evin, ${ }^{20}$ and Act No. 89-1014, adjusting the Insurance Code to the opening of the European market, ${ }^{21}$ referred to as loi Bérégovoy.

Originally, the provisions of Title IV of Book I CA were classified as default norms. Under the Regulation of 30 January $2009,{ }^{22}$ the rule of Article L. 111-2 CA was amended so that the provisions of Book I Title IV of the Code, governing group insurance contracts, were given the status of mandatory provisions (ius cogens). ${ }^{23}$ Under the version of Article L. 111-2 CA that is currently in force, the provisions of Book I Titles I, II, III and IV of the Code may not be modified by the intention of the parties. However, the legislator stipulates that the said principle does not relate to provisions which expressly provide for such an eventuality and which were

\footnotetext{
14 CA-French Insurance Code (Code des assurances; JO 1978, p. 1088, modifié [amended]).

15 Mayaux (2007), p. 640.

16 Bigot-Gonçalves (2009), p. 20.

17 See http://www.legifrance.gouv.fr/affichCode.do?cidTexte=LEGITEXT000006074067 (last accessed: 1 June 2015).

18 See http://www.legifrance.gouv.fr/affichCode.do?cidTexte=LEGITEXT000006073189 (last accessed: 1 June 2015).

19 Act No. 89-1009 of 31 December 1989 reinforcing the safeguards for persons insured against certain types of risk (La loi no 89-1009 du 31 décembre 1989 renforçant les garanties offertes aux personnes assurées contre certains risques, JO du 2 janvier 1990).

20 Rigaud, Baron and Pignaud (2009), p. 465.

21 Act No. 89-1014 of 31 December 1989 adjusting the Insurance Code to the opening of the European market (Loi no 89-1014 du 31 décembre 1989 portant adaptation du code des assurances à l'ouverture du marché européen, JO no 2 du 03.01.1990).

22 Ordonnance no 2009-106 du 30 janvier 2009 portant sur la commercialisation des produits d'assurance sur la vie et sur des opérations de prévoyance collective et d'assurance, JORF no. 0026 of 31 January 2009, pp. 1838 et seq.

${ }^{23}$ Ponge (2010), p. 57.
} 
exhaustively listed in Article L. 111-2 CA. It is significant that the norm under Article L. 111-2 CA does not list as default norms any of the provisions of Title IV of Book I of the Code. ${ }^{24}$ The mandatory character of the rules devoted to group insurance contracts should come as no surprise. Bearing in mind the limited possibility of members of the group of insured parties to influence the contents of the insurance contract, granting extensive contractual freedom to the parties to such contracts could infringe the interests of the collectivity covered by insurance protection.

It must be noted that the French legislator has also introduced specific solutions for group insurance contracts outside Book I Title IV of the Code. Under Article L. 132-7 CA, life insurance is invalid if the insured party has committed suicide during the first year of the term of such an agreement. This norm, however, does not apply to group insurance contracts ${ }^{25}$ mentioned in Article L. 141-1 CA signed by the parties listed in Article L. 141-6 CA. Pursuant to Article L. 132-23 CA, in group insurance contracts in which the risk relates to the end of working life, including supplemental insurance for public officials, it is inadmissible to stipulate the right to surrender a policy.

French law is characterized by a tendency to enact special provisions for generic categories of group insurance. Act No. 2003-775 of 21 August 2003 introducing a pension reform, ${ }^{26}$ referred to as loi Fillon, established the normative framework for the operation of group insurance contracts serving as pension insurance. Another area which attracted the legislator's special attention was the sector of elective insurance for employees and persons performing work on a basis other than an employment contract. ${ }^{27}$

Unlike in French law, a feature that is characteristic of German law is the existence of only rudimentary rules on group insurance. This may be surprising, bearing in mind that the currently applicable Act on the insurance contract only entered into force on 1 January 2009. ${ }^{28}$ The German legislator decided to introduce a new legislative act in view of the fact that adaptation to today's challenges faced by the Insurance Law Act which had been in force for nearly 100 years would not be possible by implementing minor legislative amendments. ${ }^{29}$ The attitude of the legislator to reforming insurance law was based on a far-reaching review of the insurance relationships' regime.

However, in the said Act there is no comprehensive set of provisions governing group insurance contracts. What is more, the German legislator did not decide to formulate a definition of group insurance although that term is used in the Act. The distinctive feature of the German legislative framework of group insurance is the legislator's care in ensuring that the insured parties have the right to continued

\footnotetext{
24 See Bzdyń (2011), p. 200.

25 This solution, however, is criticized in the doctrine. See Courtieu (1999), p. 2.

${ }^{26}$ La loi du 21 août 2003 portant réforme des retraites, JO du 22 août 2003.

27 Bigot-Gonçalves (2009), pp. 40-41.

28 German Act on the insurance contract of 23 November 2007 (Versicherungsvertragsgesetz, Das Bundesgesetzblatt, p. 2631; hereinafter: VVG).

29 See Heiss (2012), p. 105 and the legislative materials cited therein.
} 
insurance protection. Only in this context does the new Act mention group insurance contracts ( $\$ 206$ and $\S 207 \mathrm{VVG})$.

The few legal systems in which the legislator has decided to introduce a definition of the group insurance contract include the Scandinavian countries. In Swedish law, ${ }^{30}$ it is defined as an insurance contract under which protection is afforded to a group of persons. ${ }^{31}$ The provision of $\S 2$ item 6 of the Finnish Act $^{32}$ defines the group insurance contract as an insurance contract in which protection is or may be afforded to members of a group specified in the insurance contract. In Norwegian law, ${ }^{33}$ the group insurance contract is defined as insurance in which the rights and obligations of the group members are defined by an agreement concluded by the policyholder in the name or on behalf of the group members $(\S 1-2$ letter $d$ of the Norwegian Act on the insurance contract).

A controversial method of regulating group insurance contracts was used by the Turkish legislator in the new Commercial Code, ${ }^{34}$ applicable as of 1 July 2012. It must be noted that the Turkish regime is strongly inspired by the works on the uniform insurance contract law, ${ }^{35}$ carried out with the use of comparative law research. Among the provisions on the insurance contract (Arts. 1401-1520 TTK), there is only one article on group insurance (Article 1496 TTK). Within the framework of that provision, the legislator attempted, at least partially, to regulate such issues which have given rise to doubts among insurance law experts, starting from the definition of group insurance, and ending with the question of the individual continuation of insurance protection. It should be mentioned that the legislator recognizes the need to regulate insurance contracts more extensively. Under the delegation of legislative powers provided for in Article 1496(5) TTK, questions expressly listed by the legislator (including but not limited to the surrender of a policy or notification requirements in group insurance) and-which may come as a surprise- 'other questions that are material to the group insurance contract' will be regulated in secondary legislation. It is not recommended that such a legislative technique should be followed.

Poland, on the contrary, is an example of a legal system in which the legislator does not pay any attention to group insurance. Group insurance contracts are concluded under the principle of freedom of contract (Art. $353^{1} \mathrm{CC}$ ) and according to the mandatory provisions contained in Book III Title XXVII of the Civil Code. ${ }^{36}$

\footnotetext{
30 Swedish Act on the insurance contract 2005, Försäkringsavtalslag (SFS 2005:104), available at: https://www.riksdagen.se/sv/dokument-lagar/dokument/svensk-forfattningssamling/forsakringsavtalslag -2005104_sfs-2005-104 (last accessed: 5 April 2019).

31 More in Hjalmarsson (2008), pp. 91-92.

32 Finnish Act on the insurance contract No. 543/1994 of 28 June 1994, Vakuutussopimuslaki 28.6.1994/543, Författningssamling 1450, available at: https://www.finlex.fi/en/laki/kaannokset/1994/ en19940543_20100426.pdf (last accessed: 21 October 2019).

33 Norwegian Act on the insurance contract, Act of 16 June 1989 No. 69, available at: http://www.aida. org.uk/pdf/NORWAY\%20Insurance\%20Contracts\%20Act\%201990-2009.pdf (last accessed: 5 April 2019).

34 Türk Ticaret Kanunu (TTK), 13.1.2011, No.: 6102, Resmi Gazete 14.2.2011, No. 27846.

35 Atamer et al. (2012), p. 5.

36 Handschke, Kęszycka and Kowalewski (2007), p. 5; Serwach and Kliszcz (2010), p. 33.
} 


\section{The Legal Characteristics of the Group Insurance Contract Law}

In the literature, multiple attempts have been made to expound the legal nature of the group insurance contract. Particularly rich in this regard is the legacy of French literature, which may serve as an example for the intense development of the science of insurance law. Still, there is no unanimity as to the nature of the legal relationship arising from the conclusion of a group insurance contract. Efforts by representatives of the French literature must be discussed on two levels on which the doctrinal discussion was conducted.

On the first level, research has attempted to answer the question whether, in the context of group insurance, one or more contracts are concluded. According to the historically older concept, referred to as 'unitarian', the existence of only one agreement is sufficient for the emergence of protection, that is the agreement between the insurer and the group organizer (the policyholder). On the other hand, the second position (the concept of 'éclatée'), adhered to by the vast majority of contemporary authors, is based on the assumption that apart from the contract between the insurer and the group organizer, there are simultaneously as many separate insurance contracts as there are insured parties. For the purpose of this study, this view will be referred to as the concept of the 'dispersed' insurance relationship.

The above is, however, only one of the two mentioned levels of the dispute on the juridical nature of the group insurance contract. This nature cannot be analyzed in isolation from the question concerning the legal character of the relationships arising under a group insurance contract. The legislator has not expressly resolved the question of which legal construction allows insurance protection to be provided to group members. In academic writing, many proposals have been formulated to comprehensively govern the nature of that contract. Most of the attention, however, was paid to three proposals. The first one was based on the belief that the policyholder acts on behalf of the parties insured within a group on the basis of a negotiorum gestio (gestion d'affaires). The second proposal was that the group insurance contract is, in fact, an insurance for the account of another (assurance pour compte). Proponents of the third proposal pointed out that as a consequence of concluding the insurance contract, the insurer himself makes a promise to enter into insurance contracts with the interested parties (promesse d'assurance). None of the above proposals has met with universal acceptance. In the doctrine, it did not go unnoticed that although the specific concepts allow for certain mechanisms that are characteristic of group insurance contracts to be taken into account, none of them convincingly expounds all the aspects of the construction of such contracts. The shape of the contemporary discussion on the status of group insurance was however influenced by the second and the third of the above-mentioned proposals. While the second proposal (the group insurance contract as insurance for the account of another) inspired, in the first place, proponents of the unitarian theory, the third proposed model was developed by representatives of the concept of the dispersed insurance relationship.

In French law, as a part of a single substantive law system, a distinction is made between accessory (compulsory) group insurance (assurance de groupe à 
l'adhésion obligatoire), in which insurance protection arises automatically on the date of the acquisition of a group member status and follows from the contract concluded by the group organizer (the policyholder) with the insurer, and elective group insurance (assurance de groupe à l'adhésion facultative) in which accession to a group insurance is a consequence of submitting to the insurer a notice of intention to join the circle of insured parties or the absence of a refusal to accede to the insurance. ${ }^{37}$ The latter type of insurance creates a peculiar legal construction, amounting to a combination of individual insurance with a special type of framework agreement between the insurer and the group organizer. Such a framework agreement is not an insurance contract as such. An individual insurance contract, on the other hand, ties each member of the group (the insured person) to the insurer. ${ }^{38}$ As a rule, it is concluded, with the effect of granting insurance protection, as a consequence of a declaration of accession being made.

Similarly, in the German literature, authors differentiate between the so-called proper group insurance contract (echte Gruppenversicherung), in which the group organizer is at the same time the policyholder, and the so-called improper group insurance contract (unechte Gruppenversicherung), which is based on the abovementioned construction of a framework agreement between the organizer and the insurer. $^{39}$

The same solution was also adopted by the drafters of the model regulation of insurance contracts, the Principles of European Insurance Contract Law (PEICL), ${ }^{40}$ which has been drawn up taking into consideration the results of comparative law research. The researchers from the Restatement Group decided to make a distinction between accessory (compulsory) group insurance (Art. 18:201 PEICL) and elective group insurance (Art. 18:301 PEICL). ${ }^{41}$

The research devoted to the legal character of group insurance contracts concentrated on answering the question of whether, in the context of group insurance, one or more contracts are concluded. According to the historically older concept, referred to as 'unitary', it is sufficient that only a single contract exists, concluded between the insurer and the group organizer (the policyholder), for protection to be established. ${ }^{42}$ The other approach (the concept of 'éclatée'), known as the concept of a 'dispersed' insurance relationship, is based on the presumption that besides the contract between the insurer and the group organizer, there are simultaneously as many separate insurance contracts as there are insured persons. ${ }^{43}$ In group insurances, where the construction of insurance for the account of another is utilized, there are a number of insured persons under the same contract.

\footnotetext{
37 More on the considered conceptions of the group insurance contract in Fras (2015), pp. 400-402.

38 Bigot (2002), pp. 132 et seq.; Mayaux (2007), pp. 666 et seq.

39 More in Herdter (2010), pp. 14 et seq.; this terminology was coined by Millauer (1954), pp. 107 et seq.

40 Lakhan and Heiss (2010), pp. 1-11.

41 Basedow et al. (2016). The full PEICL document is available on the website: https://www.uibk.ac.at/ zivilrecht/restatement/sprachfassungen/peicl-en.pdf.

42 Goldie-Genicon (2008), p. 2448; Mayaux (2007), pp. 655-656.

43 Mayaux (2001), pp. 347 et seq.; Mayaux (2007), pp. 661-664.
} 


\section{The Concept of Group Insurance in Private International Law}

The Rome I Regulation does not include any special conflict of laws rules concerning group insurance contracts, which has been criticized in academic writing, ${ }^{44}$ but in Article 1 paragraph 2 letter ( $\mathrm{j}$ ) it does contain a clear exclusion of its application to insurance contracts arising out of operations carried out by organisations other than undertakings referred to in Article 2 of Directive 2002/83/EC of the European Parliament and of the Council of 5 November 2002 concerning life assurance the object of which is to provide benefits for employed or self-employed persons belonging to an undertaking or group of undertakings, or to a trade or group of trades, in the event of death or survival or of discontinuance or curtailment of activity, or of sickness related to work or accidents at work. This denotes that Rome I will not apply to insurance governed by public law, such as social insurance, health insurance, and employee insurance concerning occupational accidents or occupational illnesses. Nevertheless, such insurance contracts do in some ways resemble group insurance contracts because they also include the multiplication of persons who are insured. The main difference is, however, that in the contracts excluded under Article 1 paragraph 2 letter (j) of Rome I, the insurer is a public entity laid down in specific statutes, with defined competences and obligations, usually connected with the social welfare system of a given country.

Under the applicable legislative framework, there is no clear answer to the question of how group insurance contracts ought to be dealt with in the context of private international law. Such complications may be illustrated by the difficulties in identifying the law that is applicable to a framework agreement concluded between a group organizer and an insurer where accession to the insurance contract is elective. It is the result of a qualification that conclusively decides whether a contract between a group organizer and the insurer is, essentially, covered by the scope of application of the special conflict of laws rules relating to insurance contracts. There should be no doubt that the source of the difficulties is a specific, subjective framework found in the context of group insurance contracts, which consists of the multiplication of the number of insured persons and the specific position of the insurer. These features of group insurance lead to a situation in which the insurer must frequently suffer from the phenomenon of 'multiple jurisdictions' under a single insurance contract. ${ }^{45}$

When analyzing group insurances from the perspective of conflict of laws, one should also take into account the current tendencies in the development of private international law. The basic function of conflict of laws rules is to delimitate the areas of operation of isolated legal systems by determining their applicability. ${ }^{46} \mathrm{In}$ the traditional approach, this was not only the primary but also the exclusive function of private international law. The results of the designation of conflict of laws

\footnotetext{
44 Kramer (2008), p. 41.

45 Seatzu (2003), p. 175.

46 See Pazdan (2012), p. 20.
} 
were independent of the consequences of applying the proper law. ${ }^{47}$ However, as private international law developed, it was noticed that conflict of laws rules, just as substantive law provisions, may operate as a means allowing for the realization of certain values of special importance to the legislator. ${ }^{48}$ In effect, norms of private international law do not have to be neutral from an axiological perspective. ${ }^{49}$ This tendency is referred to as the 'substantivation' of private international law. ${ }^{50}$

One of the manifestations of such 'substantivation' of private international law is the trend of affording additional protection to policyholders and insured persons who are considered to be the 'weaker parties' in an insurance contract. This direction in the development of conflict of laws rules was already initiated in the draft insurance directives drawn up in the late 1960s and early 1970s. ${ }^{51}$ The group of persons afforded special protection by the provisions of private international law

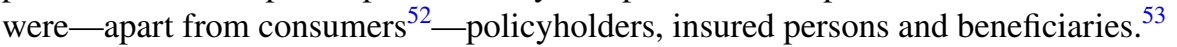

The question arises whether the special protection in the field of conflict of laws regulation may also be taken advantage of by a group member insured within the framework of accessory (compulsory) group insurance. It must be stated that the private international law protection of a 'weaker party' in an insurance contract is based on the conviction that the policyholder is an actor who independently enters into the contract with an insurer which has an economic potential that is higher than his own. A member of the group, on his part, does not enter into the insurance contract with the insurer. The significance of the doubts mentioned earlier may be evidenced by the fact that analogical doubts have been raised in the context of specific national legal systems. Because of the absence of any direct contractual connection with the insurer, a member of the group may not resort to the German Insurance Ombudsman in the event of a violation of his rights by the insurer. The German equivalent of the Insurance Ombudsman has no competence to examine matters relating to third party claims asserted against insurance companies. Activities on behalf of such third parties may be taken exclusively by the policyholder, who, however, is not always interested in an outcome which is favourable to the insured persons. ${ }^{54}$

Considering that there is no conflict of laws rule whose scope would be delimited by recourse to the concept of a group insurance contract, under the currently applicable legislative framework there is no need for its qualification. Such a procedure consists of an interpretation of the expressions determining the scope of the conflict of laws rule undertaken to define the conditions for its application. ${ }^{55}$ This

\footnotetext{
47 M. Czepelak correctly points out that even in the traditional model of private international law the results of applying the proper law may then be adjusted by resorting to the public order clause or similar institutions. Czepelak (2008), p. 202. See also Pocar (1980), p. 353 and the literature cited therein.

48 Pocar (1980), p. 357.

49 Jagielska (2010), pp. 3 et seq.

50 Jagielska (2010), pp. 3-4.

51 Kropka (2010), p. 22.

52 Instead of many others, see Fernández Arroyo (2012), pp. 154-156.

53 González Campos (2001), pp. 385-387.

54 Basedow (2007), p. 57.

55 See Pazdan (2012), p. 58.
} 
does not mean, however, that from the perspective of private international law the group character of an insurance contract is meaningless. Such ignorance may lead to a situation in which a dispute between the insurer and the insured person is merely identified as individual insurance, whereas the analysis of the broader context of the matter might allow a multi-actor framework of the group insurance contract to be detected. As a consequence, it seems that the only impulse for an in-depth analysis of a given situation is the multiple number of insured persons who form a collectivity which is somehow connected with the policyholder (the group organizer) and this cannot be disregarded during the conflict of laws evaluation.

\section{Problems with Identifying the Law Governing a Group Insurance Contract}

Under the Rome I Regulation, the least complicated procedure is determining the statutory instrument that regulates an insurance contract covering large risks. The classification of a contract as insurance against large risks is effected according to the nature of the activity conducted by the policyholder ${ }^{56}$ or its scale. ${ }^{57}$ This observation leads to the conclusion that a group insurance contract may incorporate insurance covering large risks or mass risks, although from the point of view of the individually insured persons the terms and the object of the insurance are identical. It is the policyholder and the insurer that choose the law which governs the contract concluded in relation to large risks. When it comes to members of the group, they are bound by that choice. ${ }^{58}$

Pursuant to Article 3(1) second sentence of the Rome I Regulation, the choice of law may be made expressly or it may clearly follow from the provisions of the contract or the particular circumstances. A circumstance which may suggest an implied choice of law is a functional connection between a few obligational relationships. ${ }^{59}$ Such an opinion is substantiated by a presumption that the parties may be interested in submitting the bundle of contracts to one applicable legislation. Because of the differences among specific legal systems, it must be considered rational to strive for a situation in which all the relationships under a group insurance contract are governed by the same law which governs the internal relationship between the insured persons and the policyholder.

It should be emphasized that in the case of insurance covering large risks (these are certain types of risks, especially associated with the size and type of the insured business, e.g. insurance covering railway rolling stock, aircraft, ships, and insuring professional or commercial activity) the legislator does not assign the law governing the contract to the law of the country where the risk is situated. In the absence of a choice of law, the law governing the contact is decided by the domicile of the

\footnotetext{
56 See the provision of Art. 5 letter d item (ii) of the First Council Directive 73/239/EEC.

57 See the provision of Art. 5 letter d item (iii) of the First Council Directive 73/239/EEC.

58 Heiss (2008a), p. 278.

59 Stone (2010), p. 308.
} 
insurer. As far as insurance against large risks is concerned, in principle, the rule under Article 7 paragraph 6 of the Rome I Regulation does not apply as this provision leads to the severance of the law governing the contract. This rule refers solely to insurance against mass risks and compulsory insurance-including those which relate to large risks.

The determination of the country in which the risk is situated is only of secondary importance where the parties omit to choose the law and an adjustment of the conflict of laws designation is possible according to the third sentence of Article 7(2) of the Rome I Regulation. In pursuance of that provision, in the absence of a choice of law for an insurance contract against large risks, where all circumstances of the case clearly indicate that the contract has much closer connections with another country, the law of that other country will apply.

It is much more difficult to engage in a conflict of laws analysis of insurance contracts covering mass risks which denote risks that cannot be classified as 'large' risks. Mass risks include insuring smaller economic activities and consumers, but exclude risks related to transport. In doctrine, a number of proposals have thus far been formulated which are intended to permit the designation of the law applicable to obligations under group insurance contracts.

F. Seatzu points out that the starting point for the deliberations concerning the conflict of laws status of group insurance is to differentiate the contract between the policyholder (master policyholder) and the insurer, on the one hand, from the legal relationships between the parties which are specific members of the group, on the other. ${ }^{60}$ Seatzu-invoking the case law of the Supreme Court of the United States, which, in the opinion of that author, retains its validity also in the European context-indicates that a policy issued to individual insured persons is not a precondition for the establishment of a separate insurance relationship. It only confirms that a contract has been concluded by the group organizer. The documentation prepared as a result of the interaction between the insurer and the insured person is only proof that a contract has been concluded by the group organizer. Consequently, the leading role is played by the contract concluded between the group organizer (the policyholder) and the insurer. The law applicable to the relationship between the policyholder and the insurance company is at the same time authoritative for evaluating the relationships between the insured persons and the insurer. ${ }^{61}$ Seatzu notices, however, that apart from documents which merely confirm the existence of insurance protection, there may be other documents which are the source of specific rights and obligations imposed on both the insured person and the insurer. In such an event, they are subject to the proper law as determined under the conflict of laws rule which is mandatory for a given obligation. ${ }^{62}$

It seems that the point of view taken by Seatzu may be elusive. The author focuses, in the first place, on the circulation of documents between specific participants in an insurance relationship. This approach is characteristic of the position

$\begin{array}{ll}{ }^{60} & \text { Seatzu (2003), p. } 176 . \\ 61 & \text { Seatzu (2003), pp. 176-177. } \\ 62 & \text { Seatzu (2003), pp. 176-177. }\end{array}$ 
reflected in the case law of the United States, which opts for the submission of a group insurance contract to the law of the country in which the contract organizing the insurance contract was concluded (master policy situs) or to the law of the country in which the certificates of accession to the insurance were issued (plan member booklet situs). ${ }^{63}$ Such a concept is only compatible with continental private international law to a limited degree. In a country with a common law system, such models for resolving conflicts of laws involve the need to take into account all the circumstances of the case before delivering a decision which is just from a conflict of laws perspective. ${ }^{64}$ In continental legislations, an actual connection between a given situation and a specific legal system may only translate into a conflict of laws designation in a small number of cases. ${ }^{65}$ The significance of the connecting factors relating to the location of performing the act is limited, in the first place, to the determination of the statute which regulates the contract.

An advantage of the concept put forward by Seatzu is that it takes into consideration the distinctive characteristic of the continental legal doctrine between accessory (compulsory) group insurance contracts and those contracts in which accession thereto is elective. The author seems to notice that group insurance contracts do not form a homogenous category. He points at the possibility of there being insurance documents which result in the emergence of new rights and obligations as a part of the relationship between the insured person and the insurer. An analysis of the obligational ties between the interested parties should not, however, be limited to whether a policy or certificate confirming the insurance protection has been issued. The decisive factor is whether, as a result of the activities pursued by the insured person and the insurer, a new legal relationship has arisen, which creates a source of insurance protection.

A voice in the discussion on the status of group insurance contracts in private international law which cannot be neglected are the opinions presented by H. Heiss. This author presented a proposal to introduce a far-reaching amendment to the wording of the provision of Article 7 of the Rome I Regulation. ${ }^{66}$ With regard to claims asserted by an insured person, the law applicable to a group insurance contract ought to be designated by conflict of laws rules relating to individual insurances. Such a proposal is accompanied by the presumption that the insured person has the status of a policyholder and the group organizer is considered to be a representative of the insurer. If a group insurance contract has been concluded by an employer for the account of its employees, the parties may choose the law of the country in which the employer has its head office or in which the establishment where the insured persons perform their work for the employer is situated. ${ }^{67}$ It must be stressed that those principles only hold true as long as the matter pertains to "claims asserted by the insured person'. The proposal by Heiss involves the severance of the statutory instrument

\footnotetext{
63 Stempel (2006), pp. 4-58.

${ }^{64}$ See Zachariasiewicz (1995), pp. 181 et seq.

65 See Art. 4 para. 3 and Art. 7 para. 2 third sentence of the Rome I Regulation.

${ }^{66}$ Heiss (2008a), p. 278; Heiss (2008b), p. 475.

67 Heiss (2008a), pp. 282-283.
} 
(dépeçage) established separately in relation to each member of the group who has decided to exercise his rights. Only in such cases is a group member considered to be a policyholder. The decision concerning the qualification of the contract from the point of view of the distinction between insurance contracts covering large risks and insurance contracts covering mass risks is made from the perspective of a group member. ${ }^{68}$ On the other hand, the relation between the group organizer and the insurer is characterized by conflict of laws' independence.

U.P. Gruber, who does not question Heiss's pertinent observation, argues that there is no need to introduce any special conflict of laws rule for group insurance contracts. The desired result may be achieved by the interpretive procedures proposed by that author. In the opinion of Gruber, one should abandon the traditional understanding of the concept of the insured person and use it in relation to a member of a group composed of insured persons. From the point of view of conflict of laws rules it is the insured person that ought to be regarded as the policyholder, and not the group organizer who enters into the contract with the insurance company. ${ }^{69}$ Any possible doubts concerning the proposed direction for the interpretation of the provisions of the Rome I Regulation may be dispelled, in the view of the author, by introducing a suitable explanation in the preamble to the Regulation. ${ }^{70}$ The argumentation presented by Gruber is partly consistent with the position of Heiss, who notes that, from a functional perspective, accession to an insurance contract demonstrates striking similarities to the conclusion of an individual insurance contract. ${ }^{71}$ As a consequence, for the purposes of the application of conflict of laws rules, one may not reject a limine the possibility to recognize the insured person as the policyholder.

This concept, however, is only seemingly convergent with the mechanism applied by the drafters of the Rome I Regulation. According to Article 7 paragraph 5 of the Rome I Regulation, for the purposes of paragraph 3 indention three (scil. in the absence of a choice of law for insurance contracts covering mass risks situated in the territory of the Member States) and paragraph 4 (referring to compulsory insurance) in the event that the contract covers risks situated in more than one Member State, it is considered that the contract is composed of a few agreements, each of them relating solely to one Member State. The legislator intends to adopt a legal fiction which leads to the severance of the statutory instrument regulating the contract. $^{72}$ The liability of the insurer relating to each of the risks is then considered separately in pursuance of the law of the country where the risk is situated. ${ }^{73}$ In the same way, there is no need to seek the 'centre of gravity' for the relationship under

\footnotetext{
68 Heiss (2008a), p. 278.

69 Gruber (2009), p. 125.

70 Gruber (2009), p. 125.

71 Heiss (2008a), p. 278.

72 Martiny (2010), p. 728; Heiss (2008a), p. 277.

73 The limits of the choice of law set out in Art. 7 para. 3 item 1 letter a are modified by Art. 7 para. 3 item 1 letter e of the Rome I Regulation. This provision applies both to life insurance contracts and non-life insurance contracts. An example of such a life insurance contract is a group life contract for the benefit of employees of a few branches situated in different Member States.
} 
an insurance contract. ${ }^{74}$ Unlike in the case of insurance against large risks (Art. 7(2) third sentence), with regard to insurance contracts covering mass risks the legislator has not provided for the possibility of applying an adjustment clause which might influence the result of the conflict of laws designation.

The provision of Article 7 paragraph 5 of the Rome I Regulation refers only to instances of the intra-EU location of risks. ${ }^{75}$ A clue determining the course of action where the contract covers more than one risk, out of which at least one is situated in a Member State and at least one in a third country, has been included in Recital 33 of the Rome I Regulation. ${ }^{76}$ The designation of the proper law under Article 7 of the Rome I Regulation is only made in relation to the risk or risks situated in the Member States. To the remaining extent, the statutory instrument regulating the contract is determined according to general terms set out in the Rome I Regulation. ${ }^{77}$ Additionally, the provision of Article 7 paragraph 5 of the Rome I Regulation does not refer to situations in which the risk is situated in more than one location within the legal area of the same country. ${ }^{78}$ In such a situation, there is no need to consider the group insurance contract as a bundle of individual insurance arrangements.

However, it should be emphasized that under the Rome I Regulation the location of the risk is not decided by any circumstances relating to the insured person. The technical legal concept of 'the state in which the risk is situated' is defined by reference to insurance directives. In all cases in which the provisions of the directives refer to a specific person, they refer to the policyholder, and not the insured person. As a consequence, in the event of civil liability insurance, the country where the risk is situated is not the state of residence of the insured person but the state of where the insurer is domiciled.

This assertion may be surprising especially in light of the analysis of the wording of the Polish language version of the Non-life Insurance Directive. ${ }^{79}$ In the context of the domestic regulation, in the case of insurance contracts other than life insurance, which do not amount to building insurance, tourist insurance or motor insurance, for which Article 2 letter $d$ of the Directive defines the location of the risk differently, the location of the risk is determined by the permanent residence of the insured person or, where the insured person is a juridical person, the seat of the establishment of the undertaking to which the contract refers. The analogical normative contents have been prescribed in the German text of the Directive.

However, under Article 2 letter $d$ indent four of the French version of the same Directive, the location of the risk is determined by the place of residence of the policyholder (Fr. preneur d'assurance), a concept which the Directive clearly

\footnotetext{
74 Staudinger (2015), p. 279.

75 Kropka (2013), commentary to Art. 7, item 12.

76 A view is presented in the literature on the subject that, in this respect, the role of the preamble to the Rome I Regulation is not exhausted by an explanatory function but has an important normative character. Cf. Staudinger (2015), p. 279.

77 Heiss (2008b), p. 461.

78 Merrett (2009), p. 54.

79 This Directive was repealed under Art. 310 of the Directive 2009/138/EC.
} 
distinguishes from the notion of the insured party (assuré).$^{80} \mathrm{~A}$ similar terminological distinction has been preserved in the English version of the Directive, which as such was originally drawn up in English. In Article 2 letter d indent four, one can find the term policy-holder,${ }^{81}$ whereas in other provisions, just as in the French version, the legislator has used the term insured person. An analysis of the case law of the Court of Justice of the European Union leads to the conclusion that Article 2 letter $\mathrm{d}$ indent four of the Directive should be interpreted as intending to relate the location of the risk with the person of the policyholder ${ }^{82}$ despite the linguistic discrepancies found in specific legal systems. ${ }^{83}$

As a side-note, it must be mentioned that under Article 310 of Directive 2009/138/EC, as of 1 January 2016 the Non-Life Insurance Directive was repealed. The provisions of the Rome I Regulation which refer to the provisions of the repealed directive should be read as references to Directive 2009/138/EC. In the Polish language version of that Directive, the term 'insured person' has been abandoned in the discussed context and replaced by the term 'policyholder' (Art. 13 item 13), which will allow the above-mentioned divergences to be remedied.

A non-critical acceptance of the interpretation of the provisions of the Directive as outlined above leads to the conclusion that in the event of a group insurance contract in which insured persons reside permanently in the territories of different Member States, the risk is still situated in the country in which the policyholder is domiciled. The statutory instrument regulating a group insurance contract is thus governed by the law of the state in which the policyholder has its seat. On account of specific rules relating to the connecting factor of the location of the risk, the above rule does not apply to building insurance, motor insurance and tourist insurance. In the latter situations, the country where the risk is situated is connected to the objective element of the insurance relationship, and not personally to the insured person or the policyholder.

\section{The ECJ's Approach to the Legal Status of the Group Insurance Contract}

An interesting contribution to the discussion concerning the conflict of laws status of group insurance contracts is the decision by the European Court of Justice of 14 June $2001 .^{84}$ The question referred to the Court arose out of the application of tax

\footnotetext{
80 See, inter alia, Art. 8 para. 5 letter a.

81 Differently, Pilich (2012), p. 333.

82 See the ECJ judgment of 14 June 2001 in the case C-191/99 Kvaerner v. Staatssecretaris van Financiën [2001] ECR I-04447. The issue presented for the Court's consideration was a consequence of interpreting Art. 2 letter d indent four of the Directive as relating to the policyholder rather than a person taking advantage of insurance protection. The national court would have had no doubts if the term 'policyholder' had been replaced by 'insured person'.

83 See Opinion of Advocate General Jacobs delivered on 18 January 2001, Case C-191/00 Kvaerner plv v. Staatssecretaris van Financiën, para. 24.

84 ECJ judgment of 14 June 2001, in the case C-191/99 Kvaerner v. Staatssecretaris van Financiën [2001] ECR I-04447.
} 
law; however, in the reasoning of the decision one may find a number of considerations of a general nature which should not be overlooked in the present analysis. It does not seem justified to assign a different meaning to the same provisions of the Directive where, for the purposes of the application of conflict of laws rules, they complement the connecting factor of the location of the risk and where they are applied to determine the country of tax liability. ${ }^{85}$

The national court sought an answer to the question concerning the proper understanding of Article 2 letter d indent four of Directive 88/357, which was then replaced by the above-mentioned Article 13 item 13 of Directive 2009/138/EC, according to which 'the Member State where the risk is situated means the Member State where the insured person has his habitual residence or, if the policy-holder [as mentioned above, the Polish language version used the term "insured party"; M.F.] is a legal person, the Member State where the latter's establishment, to which the contract relates, is situated-in all cases not explicitly covered by the foregoing' indents of Article 2 letter $d$ of the Directive, namely where the insurance is other than life insurance and does not amount to an insurance of a building along with its equipment, of a motor vehicle or insurance against risks relating to travel or a holiday.

While resolving the above issue, the Court stressed that by drafting Article 2 letter $\mathrm{d}$ indent four of the Directive, the legislator intended to connect the location of the risk with the legal area in which the activity to which the risk covered by the insurance protection relates is performed. ${ }^{86}$ Following an interpretation of the discussed provision, it must be concluded that the concept of an 'establishment of an undertaking' found in Article 2 letter d of the Directive refers to all mutually related entities in a situation where one of them enters into an insurance contract under which insurance protection is afforded to all entities belonging to that group ${ }^{87} \mathrm{Lim}$ ited significance should also be assigned to the character of the relation between the policyholder and the insured persons. It is not required that they should be connected by a relationship of dependency or subordination. The possibility of recognizing the insured person as an 'establishment of an undertaking' of the policyholder is determined by whether there are any actual ties between these two. ${ }^{88}$

The principles outlined above may be related to the group insurance contract. Such a possibility was also noted by the Advocate General of the Court $^{89}$ and the European Commission. ${ }^{90}$ Both of them presented their position to the Court as a part of the proceedings which concluded with the decision mentioned above, delivered

\footnotetext{
${ }^{85}$ Cf. Staudinger (2015), p. 284.

${ }^{86}$ ECJ judgment of 14 June 2001 in the case C-191/99 Kvaerner v. Staatssecretaris van Financiën [2001] ECR I-04447) para. 46.

87 ECJ judgment of 14 June 2001 in the case C-191/99 Kvaerner v. Staatssecretaris van Financiën [2001] ECR I-04447, para. 56.

${ }^{88}$ Opinion of Advocate General Jacobs delivered on 18 January 2001, Case C-191/00 Kvaerner plv v. Staatssecretaris van Financiën, para. 49; Stone (2010), p. 365.

${ }^{89}$ Opinion of Advocate General Jacobs delivered on 18 January 2001, Case C-191/00 Kvaerner plv v. Staatssecretaris van Financiën, para. 49.

90 Opinion of Advocate General Jacobs delivered on 18 January 2001, Case C-191/00 Kvaerner plv v. Staatssecretaris van Financiën, para. 23.
} 
on 14 June 2001. In the case of a group insurance contract concluded by a policyholder which is a legal person and under which insurance protection is afforded to members of a group with regard to the risks covered by Article 2 letter $\mathrm{d}$ indent four of the Non-Life Insurance Directive, there is a situation of multiple risks, as envisaged in Article 7 paragraph 5 of the Rome I Regulation.

A literal understanding of Article 2 letter d indent four of the Directive in conjunction with Article 7(3) of the Rome I Regulation may lead to the conclusion that the said rule is only applicable where the policyholder is a juridical person. If the policyholder is a natural person, the legislator assumes that the risk is situated in the country in which the policyholder resides on a permanent basis. As opposed to the provisions concerning juridical persons, the legislator does not refer in this regard to any person other than the policyholder to whom the insurance contract 'relates'.

It must be emphasized that the above observation remains valid also with regard to group life insurance contracts. ${ }^{91}$ Under Article 1 paragraph 1 of the Directive on life insurance, to which Article 7 paragraph 6 of the Rome I Regulation refers, the country where the risk is situated is the state in which the policyholder has his habitual residence or, 'if the policy holder is a legal person, the Member State where the latter's establishment, to which the contract relates, is situated'.

The acceptance of such a point of view would lead to a conclusion which is difficult to draw, namely that the statutory instrument governing the contract is severed only where a group insurance contract is concluded by a juridical person. On the other hand, a contract concluded in similar circumstances by a natural person is not subject to dépeçage. Considering that there are no legitimate reasons to adopt this standpoint, one should depart from the literal meaning of the provisions of the Directive, in particular bearing in mind that Article 2 letter $\mathrm{d}$ indent four of the Directive allows the determination of the country where the risk is situated according to where the activity relating to such a risk is pursued. ${ }^{92}$

Finally it should be noted that the definition of the place where the risk is situated as stated in Article 13 item 13 of Directive 2009/138/EC mirrors the definition contained in Article 2 letter d indent four of Directive 88/357. Although these Directives do not concern private international law matters, they do define a key concept that private international law utilizes as a connecting factor. Therefore it is desirable to understand the place where the risk is situated in a consistent manner when considering insurance contracts, particularly when this has been defined in Directives concerning insurance activities. Rome I expressly mentions Directive 88/357, but currently that Directive has been replaced by Directive 2009/138/EC (see Art. 310).

\footnotetext{
91 Staudinger (2015), p. 284.

92 ECJ judgment of 14 June 2001 in the case C-191/99 Kvaerner v. Staatssecretaris van Financiën [2001] ECR I-04447, para. 46.
} 


\section{Interpreting the Provisions of Insurance Directives}

Additionally, one cannot lose sight of the fact that upon the entry into force of the Rome I Regulation, the context in which the provisions of insurance directives are interpreted has changed. For the purposes of the application of conflict of laws rules, interpretation procedures nowadays consist of the interpretation of the provisions of the Regulation which only borrow the contents of the directives, a reference to which was made in Article 7 paragraph 6 of the Rome I Regulation. ${ }^{93}$ A. Staudinger remarks that in its initial period of application, the Non-Life Insurance Directive was in conformity with the Brussels Convention, ${ }^{94}$ under which special protection in terms of jurisdiction had only been afforded to the policyholder. ${ }^{95}$ This changed with the entry into force of the Brussels I Regulation. The legislator decided to align the legal situations of the policyholder and the insured person, ${ }^{96}$ which, however, was not accompanied by respective amendments to the provisions of the insurance directives. Bearing in mind that the Rome Regulations and the Brussels Regulations were to enable the creation of a complete and internally non-contradictory system, ${ }^{97}$ which was to be favoured by the terminological consistency of the above pieces of legislation, ${ }^{98}$ there is no reason for special treatment to be given to insured persons only in terms of jurisdiction. ${ }^{99}$

The arguments advanced by Staudinger may, however, give rise to serious doubts. In the literature on the subject, it is argued that one should refrain from any attempts at a thoughtless transposition of solutions envisaging a jurisdictional regulation of private international law. ${ }^{100}$ Although, when analyzing the provisions of the directives, one may defend the view that their incompatibility with the solutions concerning jurisdiction is a consequence of negligence on the part of the legislator, it must be emphasized that provisions of the Rome I Regulation are also not consistent, in the area discussed, with the Brussels I Regulation. These were only jurisdictional solutions that evolved towards the expansion of the range of persons covered by

\footnotetext{
93 Staudinger (2015), p. 284.

94 The Brussels Convention of 27 September 1968 on jurisdiction and enforcement of judgments in civil and commercial matters, OJ 1998, C 27/1.

95 Under Art. 8 item 2 of the Brussels Convention, an insurer domiciled in the territory of a Member State could be sued before the courts of the state of the policyholder's residence.

96 See Art. 9 para. 1 letter b of the Brussels I Regulation (Council Regulation (EC) No. 44/2001 of 22 December 2000 on jurisdiction and the recognition and enforcement of judgments in civil and commercial matters, OJ 2001, L 12/1) and Art. 11 para. 1 letter b of the Brussels I bis Regulation (Regulation (EU) No. 1215/2012 of the European Parliament and of the Council of 12 December 2012 on jurisdiction and the recognition and enforcement of judgments in civil and commercial matters, OJ 2012, L 351/1).

97 See Pocar (2009), pp. 343 et seq.

98 Lando and Nielsen (2008), p. 1690. See also Żarnowiec (2013), p. 184.

99 A synergy between the Rome I Regulation and the Brussels I Regulation inasmuch as these legislative acts fulfil the postulate of protecting the 'weaker party' in an insurance contract was signalled, although without a wider justification, by Lein (2008), p. 187.

100 Lein (2008), p. 198; as regards attempts at a qualification of the concepts of the Rome II Regulation (Regulation (EC) No. 864/2007 of the European Parliament and of the Council of 11 July 2007 on the law applicable to non-contractual obligations, OJ 2007, L 199/40) through the prism of jurisdictional solutions, such a possibility has also been questioned. See Valdhans (2009), p. 241.
} 
special insurance protection. On the other hand, conflict of laws rules continue to concentrate predominantly on the person of the policyholder. As a part of the limited choice of law under Article 7 paragraph 3 of the Rome I Regulation, the parties to an insurance contract against mass risks are not in a position to choose the law of the habitual residence or nationality of the insured person. The connecting factors included in Article 7 paragraph 3 of the Rome I Regulation refer exclusively to the policyholder. ${ }^{101}$ At the same time, the catalogue of connecting factors was party framed so as to enable the parties to choose the applicable law which shows connections with the policyholder, that is the legal system known to the latter. ${ }^{102}$ The legislator did not decide to enact solutions which, in analogical terms, afford protection to the insured person.

Moreover, special jurisdictional norms serve a different function than conflict of laws norms. ${ }^{103}$ Jurisdictional determinations are destined to ensure the 'accessibility' of the forum to the weaker party in an insurance contract, which gives rise to the necessity on the part of the insurer to suffer from the 'plurality' of jurisdictions. Consequently, it ought to be considered whether that phenomenon simultaneously results in the insurer having to suffer from the 'plurality' of statutory instruments regulating the contract. While analyzing the consequences of the application of Article 7 paragraph 5 of the Rome I Regulation with that assumption in mind, it would be difficult to resist an impression that it leads to erasing the differences between group insurance and individual insurance contracts against mass risks. From a conflict of laws perspective, a group insurance contract is dealt with as a number of individual insurances. If the intention of the parties was to enter into separate insurance contracts, they would not have decided to cover the risks with protection under a common group insurance contract. ${ }^{104}$

At this point, it must be noted that the positions represented by Heiss, Gruber and Staudinger overlook, in the conflict of laws context, the distinction between contracts in which the existence of insurance protection is a consequence of adherence to a given group (scil. accessory (compulsory) insurance contracts), and insurance relationships the accession to which is left to the interested party's discretion. Regardless of the character of a group insurance, they treat the contract concluded by the group organizer as an insurance contract.

On the other hand, the provision of Article 7 of the Rome I Regulation covers only insurance contracts sensu stricto. Returning, at this point, to the previous considerations, it must be concluded that the concept of the insurance contract should be related to such contracts in which the insurer, in exchange for a specific premium, decides to bear the risk of monetary payment to the entitled party if an occurrence of an event specified in the agreement has taken place. The element referred to as risk is characteristic of the insurance contract.

\footnotetext{
101 See Art. 7 para. 3 letter b, c and e of the Rome I Regulation.

102 Kuipers (2012), p. 121.

103 Heldrich (1969), p. 63; Schack (2002), p. 99.

104 Merrett (2009), p. 55.
} 
In accessory (compulsory) group insurance, there is only one contract under which the insurance company undertakes to bear the agreed risk as a part of the business activity it conducts. This is an insurance contract sensu stricto, and, as such, is covered by the scope of the special conflict of laws rules under Article 7 of the Rome I Regulation. On the other hand, in the event of elective group insurance contracts, the contract concluded by the organized group lacks the characteristics of an insurance contract. Under the latter, the insurer does not undertake to bear any specific risk. It covers only the insurer's undertaking to enter into insurance contracts with specific members of the group. As a result of concluding a framework agreement, on the part of the group organizer (the policyholder) or the insured persons, no definitive obligation to pay the premium will arise. On such an occasion, only the method of its calculation is determined. Consequently, it seems that such an agreement should not be given the status of an insurance contract. It should not be governed by special provisions, including the norm under Article 7 of the Rome I Regulation I.

A certain clue for an accurate qualification as a group insurance may be the opinions presented in the literature, which refer to distribution agreements. In academic writing, attempts are made to account for group insurance by reference to the model of a contract organizing a distribution network. ${ }^{105}$ The prevalent view in the doctrine is that of the independent character, in terms of conflict of laws, of contracts for the supply and sale concluded as the performance of a framework agreement. Executory contracts should be dealt with as independent contracts. ${ }^{106}$ This remark does not relate to instances where the framework agreement includes a binding and definitive undertaking to perform its specific elements. ${ }^{107}$ On such occasions there is no reason to attempt to fragment the existing obligation.

The concept presented above is also congruent with the needs of the private international law provisions on insurance contracts. In a contract to which accession is compulsory, the group organizer (the policyholder) and the insurer jointly set out the terms of affording protection to specific members of the group. Establishing protection in relation to the successively acceding persons is merely an executory act performed in accordance with the prescribed procedure. There is no clear demarcation line between a contract which would organize the group insurance and particular insurance contracts. Such a model may, however, be adjusted by the application of the mechanism provided for in Article 7 paragraph 5 of the Rome I Regulation, especially, bearing in mind that in light of the statements made by the Court, the connecting factor of the 'location of the risk' should be related to the insured person.

The construction of elective group insurance must be evaluated differently. Within its framework, it is possible to make a clear distinction between the framework agreement and executory agreements concluded on the initiative of the group members. Those insurance contracts ought to be independent from the point of view of private international law. The contract organizing an elective group insurance

\footnotetext{
105 See Fras (2015), pp. 150-165.

106 Żmij (2009), p. 31.

107 Magnus (2009), p. 42.
} 
does not fall within the scope of application of Article 7 of the Rome I Regulation because it is not an insurance contract sensu stricto. Contracts between the insured persons and the insurer are covered by the discussed provision. They all have the features of insurance contracts in the understanding of Article 7 of the Rome I Regulation.

Where protection under a group insurance contract is afforded to a group of persons, the connecting factor of the location of the risk should be determined separately for each of those persons. ${ }^{108}$ In a situation in which accession to the insurance is compulsory, this result is achieved by an appropriate interpretation of the provisions of the Directive to which Article 7 paragraph 6 of the Rome I Regulation refers. This interpretative rule should apply to both non-life insurance contracts (Art. 2 letter $\mathrm{d}$ indent four of the Non-Life Insurance Directive) and life insurance contracts (Art. 1 para. 1 of the Directive on life insurance). The adoption of this solution leads to the severance of the statutory instrument regulating the contract, which, however, was somehow the intention of the legislator (Art. 7 para. 5 of the Rome I Regulation). The conflict of laws consequence of designating the law is not dependent on the place of residence of a beneficiary under a group life insurance. The purpose of the discussed provisions of the directives was to connect the technical legal concept of the country in which the risk is situated with the legal system in which the risk may be realized. However, the circumstances relating to the beneficiary are irrelevant to the risk itself, as the latter refers to the insured person.

As far as elective group insurance contracts are concerned, the insured person is at the same time the policyholder. The role of the organized group is exhausted upon the conclusion of the framework agreement which, however, does not give rise to any concrete obligation on the part of the insurer to grant insurance protection. The need to determine the 'country in which the risk is situated' for each of the group members individually does not arise under Article 7 paragraph 5 of the Rome I Regulation. There are as many insurance contracts as there are members of the group.

Adopting that solution leads to seemingly identical results as the conflict of laws designation for both accessory (mandatory) insurance contracts and elective contracts. This observation is legitimate as long as the endeavours are limited to the search for the applicable law for the evaluation of the rights and obligations of the insured person and the insurer. The need to find the applicable law may, however, also concern the legal relationship between the group organizer and the insurer. An elective group insurance contract does not include any definitive undertaking by the insurer to afford insurance protection. As a result, the norm under Article 7 of the Rome I Regulation is not authoritative for the evaluation of the rights and obligations of the parties to the framework agreement.

Accepting this solution leads to a surprising conclusion that the special protection in the field of private international law offered by the norms of Article 7 of the Rome I Regulation is only granted to such a group organizer who enters into an accessory (compulsory) insurance contract. There are, however, no grounds to give preference to that category of group insurance contracts. This would lead to the

108 Staudinger (2010), pp. 54 et seq. 
promotion of accessory insurance contracts at the expense of elective insurance contracts. Consequently, it seems that there is a need for a revision of the assumptions relating to the qualification of the concept of an insurance contract. By delimiting the scope of Article 7 of the Rome I Regulation, one should bear in mind a specific construction of the contract organizing group insurance to which accession is elective. The contents of the obligation under that contract may not include any definitive undertaking by the insurer to grant insurance protection; however, the need to protect the group organizer in the event of a possible dispute with the insurer is an argument in favour of covering such contracts with the scope of application of the conflict of laws rules of Article 7 of the Rome I Regulation.

\section{The Scope of the Statutory Instrument Regulating a Group Insurance Contract}

The lex contractus decides on the rights and obligations of the parties to an insurance contract. The right that is applicable to an insurance contract is authoritative for the evaluation of the contents of the information and advisory duties, as well as the contents of the obligation to pay the premium. The obligations relating to the documentation of an insurance contract also fall within the scope of the statutory instrument which regulates the insurance contract. ${ }^{109}$

The law that is applicable to the contract concluded between the policyholder and the insurer decides whether an insurance contract produces consequences only between its parties or whether it affects the legal position of any third parties. ${ }^{110}$ It determines the admissibility to enter into a contract for the benefit or for the account of the insured person. ${ }^{111}$ The scope of the statutory instrument regulating the insurance contract also covers the performance owed to a third party and the conditions for an effective stipulation of a provision for the benefit of such a third party. ${ }^{112}$ Moreover, the lex contractus decides on any possible restrictions concerning the expression of consent by the person for whose benefit such performance has been stipulated. ${ }^{113}$

Additionally, the statutory instrument regulating the contract is conclusive in respect of the existence and character of the relation between the policyholder (the group organizer) and the insured person. ${ }^{114}$ It must be emphasized that the above remark relates to the relation under the insurance contract itself and not the internal relationship between those persons, which usually already exists before the conclusion of the insurance contract. In other words, the law that is applicable to an insurance contract accounts for the mechanism of granting insurance law protection to

\footnotetext{
109 See Pilich (2012), p. 383.

110 Heuzé (2002), p. 1510.

111 Heuzé (2002), p. 1510; Kropka (2007), p. 190 and the literature cited therein.

112 Heuzé (2002), p. 1509.

113 Heuzé (2002), p. 1509

114 Kropka (2007), p. 200.
} 
the extent that it answers the question of whether the group organizer is a representative of the insurer in relation to the persons seeking insurance protection.

On the other hand, the question arises whether the statutory instrument which regulates an insurance contract, as designated by the norms of the Rome I Regulation, applies to the evaluation of the consequences of acts performed by the policyholder as a representative of the insurance company. The results of comparative law analyses permit the conclusion to be drawn that, to a certain degree, the policyholder (the group organizer) is considered to be a representative of the insurance company. ${ }^{115}$ However, outside the scope of application of the Rome I Regulation there remain 'question[s] whether an agent is able to bind a principal, or an organ to bind a company or other body corporate or unincorporated, in relation to a third party' (Art. 1 para. 2 letter g). ${ }^{116}$ This exclusion extends to all issues concerning the competence of a contracting party to bind another person (the represented one), regardless of whether such competence is to follow from the intention of the principal, directly from legal provisions or the structure of the juridical person or other organizational unit. ${ }^{117}$ In answering the question whether a broker may act in a binding way on behalf of a person seeking insurance protection, this requires the applicable law to be determined under national conflict of laws rules. ${ }^{118}$ The law designated by national conflict of laws rules also decides on the binding character of an agent's acts as far as the insurer is concerned.

These rules may, however, be directly transposed to group insurance contracts. The group organizer does not perform acts on behalf of the insurer but is only an intermediary in the delivery of declarations of intention on behalf of persons seeking insurance protection. The information and advisory duties performed by the group organized towards group members are carried out in the form of the group organizer's own obligations. He does not represent the insurer in this regard. However, even in situations when, according to the statutory instrument regulating the contract, the role of the group organizer demonstrates a similarity with the legal position of a proxy, the answers to the question whether the insurer is effectively bound by the acts performed with the involvement of the organizer should be sought in the law that is applicable to the insurance contract. In the literature, it is indicated that where the principal relationship for the power of proxy is a contractual obligation, this obligation is subject to the statutory instrument which regulates the contract and this is designated by means of the norms of the Rome I Regulation. ${ }^{119}$ This comment seems to be legitimate for acts carried out with the involvement of the group organizer.

In the conflict of laws context, one must make a distinction between the internal relationship between a member of the group and its organizer, on the one hand, and the relationship established as a consequence of accession to a group insurance contract, on

\footnotetext{
115 See Fras (2015), pp. 110-120.

116 This provision refers to the normative content of Art. 1 para. 2 letter e of the Rome Convention. It seems to be recommendable to consult the opinions presented in the literature with regard to an analogical exclusion under the Rome Convention.

117 Wojewoda (2007), p. 88.

118 Merkin and Hjalmarsson (2008), p. 1124.

119 Pazdan (2014), pp. 857-858.
} 
the other. In light of the opinions voiced by authors in the German doctrine, an example of an internal relationship between the insured person and the policyholder is an employment relationship, ${ }^{120}$ which relatively often justifies entry into a group insurance contract. Such a relationship is characterized by conflict of laws' independence. The law applicable to such a relationship is designated by appropriate conflict of laws rules.

This does not mean, however, that the internal relationship has no influence on the performance of an insurance contract. By exercising the autonomy granted to them under the law that is applicable to the internal relationship, the group organizer and its members may change the premium's terms of payment. The intention of the interested parties, however, is not binding on the insurer, and may only serve as a ground for possible recourse claims. An additional argument against identifying, in the context of private international law, the internal relationship and the relationship under an insurance contract is the fact that in certain legal systems it is sufficient for accession to a group insurance that there is a factual connection between the policyholder and the insured person. This relation does not demonstrate the features of a contractual obligation. Therefore, it is not subject to the statutory instrument determined under the conflict of laws rules of the Rome I Regulation.

\section{Conclusions}

The provisions of Article 7 paragraph 3 indentions 1 and 3 of the Rome I Regulation concerning the minimum boundaries for the choice of law and the applicable law in the absence of such a choice direct a great deal of attention to the conflict of laws protection of the policyholder (which is expressly indicated in Recital 32) and, indirectly, to the conflict of laws protection of the insured person.

The conflict of laws regulation of Article 7(3) indentions 1 and 3 does not directly take into consideration the interests of third parties participating in the insurance legal relationship based on an insurance contract (this refers to Art. 7 in its entirety). ${ }^{121}$ This particularly refers to insured persons in the case of whom an insurance contract for the benefit of a third party may give rise not only to claims but also obligations (Ger. Obliegenheiten). ${ }^{122}$ Taking into consideration the lack of an adjustment rule and in the absence of a choice of law, the solution of applying the law of another country with which the contract is more closely connected means differentiating between the interests of policyholders and insurers from various Member States of the European Union. Under the conflict of laws regime of Article 7 paragraph 3 indentions 1 and 3, it is not permissible to submit an insurance contract concerning immovable property concluded for the benefit of a third party, in the absence of a choice of law, to the law of the country in which the insurance event

\footnotetext{
120 Kropka (2007), p. 195, 200 and the literature cited therein.

121 Mankowski (1996), p. 428. See the analysis of the example of an accident insurance contract between a British pharmaceutical company and a British insurer, concluded for the account of a clinical examination participant (Probandenversicherung), carried out by Deutsch (2006), p. 581.

122 Roth (1985), pp. 595-596.
} 
is to take place if the insured person has his habitual residence in that country and the contract was concluded by an insurer and a policyholder habitually residing in another country. ${ }^{123}$ This does not preclude the possibility of applying the legislation of the country in which the insured person's vital interests are centred, besides the law that generally governs the contract. ${ }^{124}$

As a rule, the interest of an actor involved in an insurance relationship who is not a party thereto in the application of a legal regime closely connected with that actor gives way to the conflict of laws interests of the parties to the insurance contract. ${ }^{125}$ An exception for group insurance contracts must be permitted. ${ }^{126}$ This exception is to be justified by the twofold influence of the collective acquisition of insurance protection on the determination of the law that is applicable to an insurance contract. First, it is beyond the powers of insured persons to apply the law of a country other than the one in which their vital interests are centred. It is not for them to decide on the conclusion of a contract governed by the laws of another country. ${ }^{127}$ Second, as far as life insurance and sickness insurance are concerned, the insurance contract is often meant to complement the state system of social security. In such situations, the interest of the state is increasing in importance as regards the application of its social security legislation to each person employed (and insured) in that state. ${ }^{128}$

Until the time when the legal provisions on group insurance are harmonized at the European level, conflict of laws legislation has to bear the burden of ensuring the predictability of court rulings and, as a consequence, also the legal security of persons taking advantage of such insurance.

Open Access This article is distributed under the terms of the Creative Commons Attribution 4.0 International License (http://creativecommons.org/licenses/by/4.0/), which permits unrestricted use, distribution, and reproduction in any medium, provided you give appropriate credit to the original author(s) and the source, provide a link to the Creative Commons license, and indicate if changes were made.

\footnotetext{
123 See the decision by the Court of Appeal in Paris (Cour d'appel de Paris) of 19 September 1997 (Soc. Lloyd's c. Compagnie Française des Surgelés et autres), Revue critique de droit international privé 1998, p. 413, in which the court abandoned the presumption of the applicability of the law of the Member State in which the risk was situated. See also the comments by the following: Poillot-Peruzzetto (1998), pp. 419-420 and Heuzé (1999), pp. 213-216. The issues concerning the presumption of the applicability of the law of the Member State in which the risk is located were also discussed in the decision by the Queen's Bench Division (Commercial Court) of 16 September 1996 (Crèdit Lyonnais v. New Hampshire Insurance Co.).

124 Roth (1985), pp. 422-425. As well Vitta (1975), p. 412.

125 Roth (1985), pp. 422-423, 596. It must be noted that the same can generally be said about practically any contract for the account of another.

126 Roth (1985), p. 423.

127 Roth (1985), p. 424. The same can be said about other insurance contracts for the account of another.

128 Roth (1985), p. 424. These remarks were reflected in Art. 13 Einführungsgesetz zum Versicherungsvertragsgesetz (EGVVG) (see no. b.137).
} 


\section{References}

Atamer K et al (2012) New Turkish insurance contract law. Free translation of the provisions of the Turkish commercial code regarding insurance contracts. October 2012. http://www.aida.org.uk/pdf/Turki sh\%20Insurance\%20Contract\%20Law.pdf. Accessed 8 June 2015

Basedow J (2007) Small claims enforcement in a high cost country: the German insurance ombudsman. In: Wahlgren P, Bernitz U, Mahmoudi S, Seipel P (eds) What is Scandinavian law? Social private law. Stockholm Institute for Scandinavian Law, Stockholm, pp 49-63

Basedow J, Birds J, Clarke M, Cousy H, Heiss H, Loacker L (2016) Principles of European insurance contract law (PEICL), 2nd expanded edn. Otto Schmidt, Cologne

Bigot J (2002) Assurance-vie. In: Bigot J (ed) Traitè de Droit des assurances, tome 3: Le contract d'assurance. LGDJ, Paris, p 132

Bigot-Gonçalves M (2009) Les assurances de groupe. Presses universitaires d'Aix-Marseille, Aix-en-Provence

Bucher A (2011) La dimension sociale du droit international privé. Nijhoff, Leiden

Bzdyń A (2011) Ubezpieczenia grupowe we francuskim 'code des assurances' [Group insurance in French 'code des assurances']. In: Kowalewski E (ed) Ubezpieczenia grupowe na życie a prawo zamówień publicznych [Group life insurance and public procurement law]. Towarzystwo Naukowe Organizacji i Kierownictwa, Toruń, p 200

Courtieu G (1999) Un suicide raté ou le législateur se tire une balle dans le pied. Gazette du Palais, 8-9 January 1999, p 2

Czepelak M (2008) Umowa międzynarodowa jako źródło prawa prywatnego międzynarodowego [An international agreement as a source of private international law]. Wolters Kluwer Polska, Warsaw

Deutsch E (2006) Das internationale Privatrecht und das internationale Versicherungsrecht der klinischen Forschung. Versicherungsrecht 57:577-581

Fernández Arroyo DP (2012) Consumer protection in private international relationships. In: Brown KB, Snyder DV (eds) General reports of the XVIIIth Congress of the International Academy of Comparative Law. Springer, Dordrecht, pp 143-165

Fras M (2015) Umowa ubezpieczenia grupowego Aspekty prawne [Group insurance contract Legal aspects]. Wolters Kluwer, Warsaw

Fuchs B (2009) Normy kolizyjne dla umów ubezpieczenia w prawie wspólnotowym i w prawie polskim-zagadnienia wybrane [Conflict of law rules for insurance contracts in Community law and Polish law-selected issues]. Rejent 1:9-32

Goldie-Genicon C (2008) L'assurance de groupe à l'épreuve de la législation sur les clauses abusives. Recueil Dalloz 2008(1):2447-2454

González Campos JD (2001) Diversification, spécialisation, flexibilisation et matérialisation des règles de droit international privé. Recueil des Cours 287:9-426

Gruber UP (2009) Insurance contracts. In: Ferrari F, Lieble S (eds) Rome I Regulation. The law applicable to contractual obligations in Europe. Sellier European Law Publishers, Munich, pp 109-128

Handschke J, Kęszycka B, Kowalewski E (2007) Problematyka grupowych ubezpieczeń na życie w świetle znowelizowanych przepisów k.c. o umowie ubezpieczenia. Spór o intencje ustawodawcy [Group life insurance issues in the light of the amended provisions of the Civil Code on the insurance contract. Dispute over the legislator intentions]. Wiadomości Ubezpieczeniowe 2007(7-8):3-15

Heiss H (2008a) Insurance contracts in Rome I: another recent failure of the European legislature. Yearb Priv Int Law 10:261-283

Heiss H (2008b) Versicherungsverträge in Rom I: Neuerliches Versagen des europaischen Gesetzgebers. In: Baetge HD, Hein J, von Hinden M (eds) Die richtige Ordnung: Festschrift für Jan Kropholler zum 70. Geburtstag. Mohr Siebeck, Tübingen, pp 459-480

Heiss H (2012) Proportionality in the new German Insurance Contract Act 2008. Erasmus Law Rev 5:105-114

Heldrich A (1969) Internationale Zuständigkeit und anwendbares Recht. Walter de Gruyter, Berlin

Herdter F (2010) Der Gruppenversicherungsvertrag — Grundlagen und ausgewählte Problemfelder. VVW, Karlsruhe

Heuzé V (1999) Note to the decision of the Court of Appeal in Paris (Cour d'appel de Paris) of 19 September 1997 (Soc. Lloyd's c. Compagnie Française des Surgelés et autres). Revue Générale du Droit des Assurances 1999(1):204-208 
Heuzé V (2002) Les assurances collectives. In: Bigot J (ed) Traité de Droit des assurances, tome 3: Le contrat d'assurance. LGDJ, Paris, pp 1509-1510

Hjalmarsson J (2008) The Swedish Insurance Contract Act 2005-an overview. Nordisk forsikringstidsskrift 1:91-92

Jagielska M (2010) Ewolucja ochrony konsumenta w prawie kolizyjnym Unii Europejskiej w zakresie zobowiązań umownych [The evolution of consumer protection in the European Union: conflict of law principles regarding contractual obligations]. C.H. Beck, Warsaw, p 2010

Kowalewski E (2006) Prawo ubezpieczeń gospodarczych [Business insurance law]. Oficyna Wydawnicza Branta, Bydgoszcz-Toruń

Kowalewski E, Bzdyń A (2012) Prawo właściwe dla umów ubezpieczenia w świetle prawa polskiego na tle regulacji europejskich [Law applicable to insurance contracts in the light of Polish law against the background of European regulations]. Wiadomości Ubezpieczeniowe 1(1):67-87

Kramer X (2008) The new European conflict of law rules on insurance contracts in Rome I: a complex compromise. ICFAI Univ J Insurance Law 6(4):23-42

Kropka M (2007) Prawo właściwe dla umowy ubezpieczenia następstw nieszczęśliwych wypadków. Glosa do wyroku Sądu Najwyższego z dnia 3 lutego 2006 r. [Law applicable to the personal accident insurance contract. Note to the Judgment of the Supreme Court of 3 February 2006]. II PK 152/05. Problemy Prawa Prywatnego Międzynarodowego 2:190-200

Kropka M (2010) Kolizyjnoprawna regulacja umowy ubezpieczenia w Rozporządzeniu Rzym I [The conflict of law regulation under the Rome I Regulation]. Wydawnictwo Uniwersytetu Śląskiego, Katowice

Kropka M (2013) Komentarz do art. 7 Rozporządzenia Nr 593/2008 [Commentary to Art. 7 of Regulation no 593/2008]. In: Pazdan M (ed) Prawo prywatne międzynarodowe. Komentarz [Private International Law. Commentary]. C.H. Beck, Warsaw, pp 100-150

Kuipers JJ (2012) EU law and private international law: the interrelationship in contractual obligations. Nijhoff, Leiden

Lakhan M, Heiss H (2010) An optional instrument for European insurance contract law. Utrecht J Int Eur Law 26:1-11

Lando O, Nielsen PA (2008) The Rome I Regulation. Common Mark Law Rev 45:1687-1726

Lein E (2008) The New Rome I/Rome II/Brussels I synergy. Yearb Priv Int Law 10:177-198

Loacker LD (2015) Informed insurance choice? The insurers pre-contractual information duties in general consumer insurance. Edward Elgar, Cheltenham

Ludwichowska K, Thiede T (2009) Reżim kolizyjny umowy ubezpieczenia po wejściu w życie rozporządzenia Rzym I [The regime of the law governing the insurance contracts after the entry into force of the Rome I Regulation]. Prawo Asekuracyjne 2:58-72

Łyskawa K (2007) Grupowe ubezpieczenia na życie z funduszem kapitałowym w systemie zabezpieczenia emerytalnego w Polsce [Group life insurance with a capital fund in the pension security system in Poland]. Fundacja Warty i Kredyt Banku 'Razem możemy więcej', Warsaw

Magnus U (2009) Article 4 Rome I Regulation: the applicable law in the absence of choice. In: Ferrari F, Lieble S (eds) Rome I Regulation: the law applicable to contractual obligations in Europe. Sellier European Law Publishers, Munich, pp 27-50

Mankowski P (1996) Versicherungsverträge zugunsten Dritter: internationales Privatrecht und Art. 17 EuGVÜ. Praxis des Internationalen Privat-und Verfahrensrechts 16:427-432

Martiny D (2010) Kommentar zum Art. 7. In: Sonnenberger HJ (ed) Münchener Kommentar zum Burgerlichen Gesetzbuch, vol X: Internationales Privatrecht. Beck, Munich, p 277

Mayaux L (2001) Note sous Cass. civ. 1re, 16 janvier 2001. RGDA 2001(1):347

Mayaux L (2007) Premiére approche. In: Bigot J (ed) Traité de Droit des assurances, tome 4: Les assurances de personnes. LGDJ, Paris, p 640

Merkin R, Hjalmarsson J (2008) Compendium of insurance law. Informa, London

Merrett L (2009) Choice of law in insurance contracts under Rome I. J Priv Int Law 5(1):49-67

Millauer H (1954) Rechtsgrundsätze der Gruppenversicherung. Verlag Versicherungswirtschaft, Karlsruhe

Orlicki M (2005) Konsumenckie prawo ubezpieczeniowe [Insurance law for consumer]. In: Nowińska E, Cybula P (eds) Europejskie prawo konsumenckie a prawo polskie [European consumer law and Polish law]. Zakamycze, Kraków, p 423

Pazdan M (2012) Prawo prywatne międzynarodowe [Private international law]. Wolters Kluwer, Warsaw 
Pazdan J (2014) Ustalenie i stosowanie prawa właściwego [Determination and application of applicable law]. In: Pazdan M (ed) Prawo Prywatne Międzynarodowe. System Prawa Prywatnego, vol 20A [Private international law. System of a private law]. C.H. Beck, Warsaw, pp 857-858

Pilch M (2012) Statut umów ubezpieczenia według rozporządzenia Rzym I [Statute of insurance contracts according to the Rome I Regulation]. In: Weit K, Grzegorczyk P (eds) Europejskie prawo procesowe cywilne i kolizyjne [European civil procedural law and conflict of laws principles]. LexisNexis, Warsaw, pp 313-385

Pocar F (1980) La protection de la partie faible. Recueil des cours 188:339-418

Pocar F (2009) Some remarks on the relationship between the Rome I and the Brussels I Regulations. In: Ferrari F, Lieble S (eds) Rome I Regulation: the law applicable to contractual obligations in Europe. Sellier European Law Publishers, Munich, pp 343-348

Poillot-Peruzzetto S (1998) Note to the decision of the Court of Appeal in Paris (Cour d'appel de Paris) of 19 September 1997 (Soc. Lluyd's c. Compagnie Française des Surgelés et autres). Revue Crit Droit Int Privé 1998(1):419-420

Ponge JC (2010) Les sanctions en droit des assurances. Harmattan, Paris

Rigaud D, Baron P, Pignaud X (2009) La prévoyance collective des salariés et la loi Evin. Droit social 2009(4):465-474

Roth W-H (1985) Internationales Versicherungsvertragsrecht. J.C.B. Mohr (P. Siebeck), Tübingen

Schack H (2002) Internationales Zivilverfahrensrecht. Beck, Munich

Seatzu F (2003) Insurance in private international law: a European perspective. Hart, Oxford

Serwach M, Kliszcz J (2010) Grupowe ubezpieczenie na życie w świetle prawa, doktryny i praktyki ubezpieczeniowej [Group life insurance in the light of law, doctrine and insurance practice]. Prawo Asekuracyjne 2010(2):33

Staudinger A (2010) Ausgewählte Probleme der D\&O-Versicherung im Internationalen Zivilverfahrens-, Kollisions- und Sachrecht. In: Lorenz E (ed) Karlsruher Forum 2009: Managerhaftung. Versicherungsrecht Schriftenreihe, vol 43. Verlag Versicherungswirtschaft, Karlsruhe, p 54

Staudinger A (2015) Commentary to Art. 7. In: Ferrari F (ed) Rome I Regulation: pocket commentary. Sellier European Law Publishers, Munich, p 279

Stempel JW (2006) Stempel on insurance contracts. Aspen Publishers, New York

Stone P (2010) EU private international law. Edward Elgar, Cheltenham

Valdhans J (2009) The pitfall of interpreting Rome II Regulation consistently with Brussels I Regulation. Jurisprudencija 116(2):229-244

Vitta E (1975) Diritto international private, vol III. Unione Tipografico-Editrice Torinese, Turin

Wojewoda M (2007) Zakres prawa właściwego dla zobowiązań umownych [The scope of the law applicable to the contractual obligations]. Wolters Kluwer, Warsaw

Zachariasiewicz MA (1995) Noweprądy w kolizjonistyce Stanów Zjednoczonych i ich wpływ na naukę europejską [New trends in United States conflict of law principles and their impact on European science]. Kwartalnik Prawa Prywatnego 2:181-225

Żarnowiec Ł (2013) Kontrakt i prawo właściwe [Contract and law applicable]. In: Popiołek W (ed) System Prawa Handlowego. Międzynarodowe Prawo Handlowe [Commercial law system International commercial law], vol 9. C.H. Beck, Warsaw, p 184

Żmij G (2009) Umowy o usługi na tle art. 4 konwencji rzymskiej [Service agreement in the light of Art. 4 Rome Convention]. Europejski Przegląd Sądowy 1(4):27-31

Publisher's Note Springer Nature remains neutral with regard to jurisdictional claims in published maps and institutional affiliations. 